\title{
EQUATIONS FOR PREDICTING HEARTWOOD MERCHANTABLE VOLUME AND TRADABLE SAWLOG IN TECTONA GRANDIS
}

\author{
Moya R*, Gaitán-Álvarez J, Ortiz-Malavassi E, Berrocal A \& Fernández-Sólis D \\ Instituto Tecnológico de Costa Rica, Escuela de Ingeniería Forestal, Apartado 159-7050, Cartago, Costa Rica \\ *rmoya@itcrac.cr
}

Submitted February 2020; accepted June 2020

\begin{abstract}
Heartwood is the most important part of the Tectona grandis tree. Although various equations for prediction of this tissue are available for this species, there are no models for prediction of its heartwood exclusively. The objective of the present study was to establish equations for predicting heartwood merchantable volume and tradable sawlog of teak trees growing in fast-growth plantations in Costa Rica. A total of 54 plantations were sampled from five regions of this country. Four equations were used to establish heartwood parameters using diameter at breast height $(\mathrm{dbh})$, total height $(\mathrm{H})$ and age as predictor variables. The equation selected for prediction of heartwood height (Hhw) and heartwood diameter (Dhw) included dbh and H. For Hhw, the equation proposed was $\mathrm{Y}=\mathrm{b}_{1}+\mathrm{b}_{2} \mathrm{H}+\mathrm{b}_{3}$ Age $+\mathrm{b}_{4} \mathrm{dbh}$, with coefficients of determination $\left(r^{2}\right)$ of 0.87 , while the stem profile equation to determine the different values of external diameter was $d u b=\mathrm{a}_{0} \mathrm{dbh}^{\mathrm{a}_{1}} \mathrm{H}^{\mathrm{a}_{2}} \mathrm{X}^{\mathrm{M}}$ with $r=0.94$, and the equation to determine the Dhw was $-4.83+0.190 \mathrm{~d}$, where $\mathrm{d}$ was any given external diameter of a tree. The selected equation could be used to predict total and commercial heartwood and quantity of sawlog of trees from plantation of T. grandis.
\end{abstract}

Keywords: Fast-growth plantation, vertical variation, regression model, prediction, stem profile equation

\section{INTRODUCTION}

Teak (Tectona grandis) is considered as one of the most commercially important tropical timber species. Teakwood has great commercial value for manufacture of various products due to its high mechanical strength, excellent physical properties, natural durability and aesthetic properties (Thulasidas et al. 2006). Moreover, the presence of heartwood in relatively high proportions in teak makes this species suitable for the wood industry as it gives higher added value (Hegde et al. 2014). Due to these desirable features, for many years, research has been focused on the study of the formation, variation and measurements of heartwood in trees growing under fast-growth conditions (Moya et al. 2014, Anish et al. 2015, Fernández-Sólis et al. 2018).

Variation and production of heartwood in trees are affected by many factors such as tree species, age, place of tree growth, growth rate, height, tree morphology (diameter and height), as well as the types and properties of the soil (Wang et al. 2010). Studies of teak trees have shown that heartwood formation is mainly associated with the age of the tree and silvicultural practices (Moya et al. 2014). Heartwood formation begins when the teak tree is four to six years of age (Moya et al. 2014, Berrocal et al. 2018) and several researches have reported the variation profile of heartwood in teak (Fernández-Sólis et al. 2018, García et al. 2011).

A set of statistical models can be developed to predict heartwood production using several variables (Kokutse et al. 2010). Among these models, there is the Garay model used by Leite et al. (2011) for teak trees, where the total height of the tree is associated with the diameter at breast height ( $\mathrm{dbh}$ ) to determine the heartwood diameter along the height of the stem. In another study, Garcia et al. (2011) used the model by Kozak (2004) to calculate the diameter of the heartwood at dbh at different height levels. Pérez and Kanninen (2003) proposed linear and nonlinear models for the estimation of heartwood diameter in teak plantations in Costa Rica, based on dbh and total height.

Various studies proposed variation models for the estimation of volume of wood in teak 
trees, including those carried out by Nunifu and Murchison (1999), Tewari et al. (2014) and Yang et al. (2020). In spite of all these studies, the models developed were established for total volume of trees and not for the heartwood alone, which is the most important part of the teak tree for trade (Moya et al. 2014).

Therefore, the objective of the present study was to develop system equations for predicting heartwood merchantable volume and tradable sawlog of heartwood in teak trees growing in fast-growth plantations in Costa Rica, by using quantifiable tree variables such as diameter at breast height, total height and age.

\section{MATERIALS AND METHODS}

\section{Sampling area}

A total of 54 fast-growth $T$. grandis plantations were sampled from various regions of Costa Rica, with tree ages varying from 2 to 22 years. The climatic conditions of the sampled region and the number of plantations sampled are shown in Table 1 and Figure 1 respectively. It must be noted that, in the case of the Atlantic region, the number of sampled trees were few and was not used in the study (Table 1).

\section{Plantations and trees sampling}

For each sampling plantation, a temporary plot $\left(531 \mathrm{~m}^{2}\right)$ was established. All trees within the plot were measured for dbh and total height $(\mathrm{H})$, and total number of trees was counted. Three defectfree trees were selected at random, close to each temporary plot, to have a total of 162 sampled trees which were straight and showed no signs of disease. From each tree, a $4 \mathrm{~cm}$ thick stem cross- section was extracted from the stump and at every $2.3 \mathrm{~m}$ towards the top up to the maximum height of the heartwood (Hhw). During this process, the height $(\mathrm{H})$ in meters (at the point at which each cross-section was extracted), was recorded.

\section{Measurement at cross-sections}

Variables measured at each cross-section were: diameter (d), diameter without bark (dub), and diameter of heartwood (Dhw). Crosssection diameters were arithmetically calculated by taking the average of two perpendicular measurements. To calculate the heartwood percentage $\left(h w_{\text {percentage }}\right)$, the area of heartwood was measured with respect to the total area of the wood disk.

\section{Predictive models}

A systems model was developed to estimate the heartwood merchantable volume and tradable sawlog in teak, to describe: equations to determine $\mathrm{Hhw}$, Dhw at any given tree diameter, tree external diameter (dud) at any given tree height $(\mathrm{h})$, and heartwood volume, which was used to derive heartwood total volume, heartwood volume merchantable and tradable sawlog production.

\section{Equation to estimate maximum heartwood height}

This equation explores the relationship between tree Hhw, tree age, total height, and dbh using scatter-plots. Different equations for prediction of Hhw were proposed (equations 1-7), including an equation that contained four dummy variables (equation 1), which represented each of the regions and could test their significance.

Table 1 Climatic conditions of the Tectona grandis plantations sampled at different locations in Costa Rica

\begin{tabular}{|c|c|c|c|c|c|}
\hline \multirow{2}{*}{ Condition } & \multicolumn{5}{|c|}{ Region } \\
\hline & North Pacific & Central Pacific & South-Pacific & Atlantic Region & Northern Region \\
\hline Annual precipitation (mm) & 1626 & 3743 & 4454 & 3567 & 1732 \\
\hline Temperature $\left({ }^{\circ} \mathrm{C}\right)$ & 27 & 27 & 27 & 27 & 24 \\
\hline Relative humidity (\%) & 73 & 84 & 75 & 86 & 86 \\
\hline Dry season & $\begin{array}{l}\text { November- } \\
\text { April }\end{array}$ & $\begin{array}{c}\text { December- } \\
\text { April }\end{array}$ & $\begin{array}{c}\text { December- } \\
\text { March }\end{array}$ & $\begin{array}{c}\text { September- } \\
\text { October }\end{array}$ & $\begin{array}{c}\text { January- } \\
\text { April }\end{array}$ \\
\hline Number of plantation & 12 & 16 & 7 & 1 & 18 \\
\hline Planted area (ha) & 500 & 500 & 500 & 100 & 3000 \\
\hline
\end{tabular}




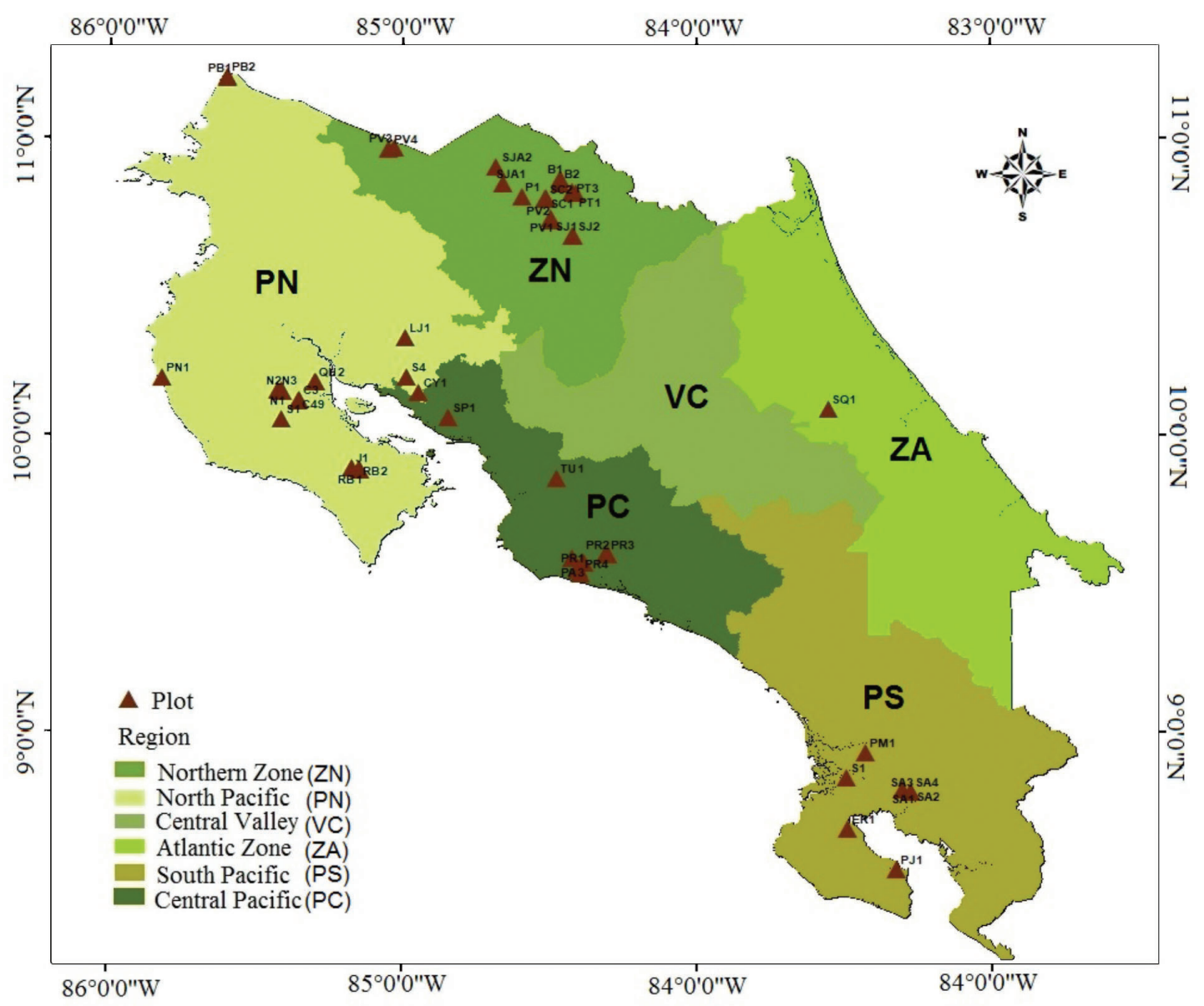

Figure 1 Distribution of sampled Tectona grandis plots of different ages in fast-growth plantations in Costa Rica

Hhw $=b_{1}+b_{2} d b h+b_{3} z_{1}+b_{4} z_{2}+b_{5} z_{3}+b_{6} z_{4}$

$\mathrm{Hhw}=\mathrm{b}_{1}+\mathrm{b}_{2} \mathrm{dbh}$

$\mathrm{Hhw}=\mathrm{b}_{1}+\mathrm{b}_{2} \mathrm{H}$

Hhw $=b_{1}+b_{2} \mathrm{H}+b_{3}$ Age

Hhw $=b_{1}+b_{2} d b h+b_{3}$ Age

Hhw $=b_{1}+b_{2} \mathrm{H}+b_{3}$ Age $+b_{4} d b h$

Hhw $=b_{1}+b_{2} H+b_{3} d b h$

where, $b_{1}, b_{2}, b_{3}, b_{4}, b_{5}$ and $b_{6}$ are model coefficients: $\mathrm{z}_{1}, \mathrm{z}_{2}, \mathrm{z}_{3}$ and $\mathrm{z}_{4}$ are dummy variables of model region effects $\left(z_{1}=\right.$ north Pacific $=1$ otherwise $=0, \mathrm{z}_{2}=$ central Pacific $=1$ otherwise $=0, \mathrm{z}_{3}=$ south Pacific $=1$ otherwise $=0$ and $\mathrm{z}_{4}=$ Atlantic region $=1$ otherwise $=0$ ), $\mathrm{H}$ is the total height of the tree, and $\mathrm{dbh}$ is the diameter at breast height.

\section{Equation to calculate heartwood diameter for any given tree diameter}

This equation was used determine heartwood diameter at different heights or at any given Dhw with diameter without bark (dub). Several models were tested and the best model was the simple linear form (equation 8):

$$
\text { Dhw }=\mathrm{b}_{0}+\mathrm{b}_{1} \mathrm{dub}
$$

where, $b_{0}$ and $b_{1}$ are coefficients, Dhw is the heartwood diameter $(\mathrm{cm})$ and dub is the diameter under bark at any given height $(\mathrm{cm})$.

Equation to estimate tree external diameter at any given tree height

This equation was developed using the recommended steps for a tree stem profile analysis. The first step in this analysis was to test the sample trees having the same profile 
by plotting the ratios of $\mathrm{d} / \mathrm{dbh}$ against $\mathrm{h} / \mathrm{H}$. The second step was to propose mathematical equations to model the stem profile observed in the plots. The taper model formulations were chosen based on the literature review. Kozak's variable-exponent taper equations (equation 9) was chosen as it has been successfully applied to many species globally including in North America, Europe, Scandinavia and Asia (Kozak 2004, Heidarsson \& Pukkala 2011, Fonweban et al. 2012). Equation 9 was also was reported to be consistently straight forward for estimating diameter under bark, tree and log volumes (Kozak 2004).

$$
\mathrm{dub}=\mathrm{a}_{0} \mathrm{dbh}^{\mathrm{a} 1} \mathrm{H}^{\mathrm{a} 2} \mathrm{X}^{\mathrm{M}}
$$

where after linearised $\mathrm{M}$ and $\mathrm{Q}$ are:

$$
\begin{aligned}
& M=b_{1}(h / H)^{4}+b_{2}\left(\frac{1}{e\left(\frac{d b h}{H}\right)}\right)+b_{3} X^{0.1} \\
& +\mathrm{b}_{4}\left(\frac{1}{\mathrm{dbh}}\right)+\mathrm{b}_{5} \mathrm{H}^{\mathrm{Q}}+\mathrm{b}_{6} \mathrm{X} \\
& \mathrm{X}=\frac{1-\left(\frac{\mathrm{h}}{\mathrm{H}}\right)^{\frac{1}{3}}}{1-\left(\frac{1.3}{\mathrm{H}}\right)^{\frac{1}{3}}} \\
& Q=1-\left(\frac{h}{H}\right)^{\frac{1}{3}}
\end{aligned}
$$

and $\mathrm{a}_{0}, \mathrm{a}_{2}, \mathrm{~b}_{1}, \mathrm{~b}_{2}, \mathrm{~b}_{3}, \mathrm{~b}_{4}, \mathrm{~b}_{5}$ and $\mathrm{b}_{6}$ are coefficients, dub is the diameter under bark $(\mathrm{cm})$, measured at height $\mathrm{h}(\mathrm{m})$ above ground, $\mathrm{dbh}$ is the diameter over bark $(\mathrm{cm})$ at breast height, and $\mathrm{H}$ is the total tree height $(\mathrm{m})$.

The other taper equations chosen were the ones developed by Shuaibu (2016), who considered the stem of the tree as a function of variables, and $\mathrm{dbh}, \mathrm{H}, \mathrm{h}$ are expressed as follows.

$$
\begin{aligned}
\mathrm{dub}= & \mathrm{b}_{0}+\mathrm{b}_{1} \mathrm{dbh}+\mathrm{b}_{2} \frac{\mathrm{h}}{\mathrm{H}}+\mathrm{b}_{3} \frac{\mathrm{h}^{2}}{\mathrm{H}^{2}} \\
\mathrm{dub}^{2}= & \mathrm{b}_{0}+\mathrm{b}_{1} d \mathrm{dbh}^{2}+\mathrm{b}_{2}\left(\frac{\mathrm{h}}{\mathrm{H}}-1\right) \\
& +\mathrm{b}_{3}\left(\frac{\mathrm{h}^{2}}{\mathrm{H}^{2}}-1\right)
\end{aligned}
$$

$\ln (\mathrm{dub})=\mathrm{b}_{0}+\mathrm{b}_{1} \ln (\mathrm{dbh})+\mathrm{b}_{2} \ln \left(\frac{\mathrm{h}}{\mathrm{H}}\right)+\mathrm{b}_{3} \ln \left(\frac{\mathrm{h}^{2}}{\mathrm{H}^{2}}\right)$

$\ln \left(\mathrm{dub}^{2}\right)=\mathrm{b}_{0}+\mathrm{b}_{1} \ln \left(\mathrm{dbh}^{2}\right)-$

$$
b_{2} \ln \left(1-\frac{h}{H}\right)-b_{3} \ln \left(1-\frac{h^{2}}{H^{2}}\right)
$$

where, $b_{0}, b_{1}, b_{2}$, and $b_{3}$ are coefficients, $h$ is the height of interest $(\mathrm{m}), \mathrm{H}$ is the total height $(\mathrm{m})$ and $\mathrm{dbh}$ is the diameter at breast height $(\mathrm{cm})$.

\section{Equation for prediction of heartwood volume}

This equation systems developed can be used to derive total heartwood volume, heartwood merchantable volume and tradable sawlog production. This equation required calculation of the heartwood volume using the information gathered, namely, Dhw (equation 8) and dub (equation 9). Heartwood volume was calculated using equation 14.

$$
\text { hwv }=\frac{\left(g_{1}+g_{2}\right)}{2} \times \text { length }
$$

where, $\mathrm{g}_{1}$ is the face area of the minor $\log$ diameter in $\mathrm{m}^{2}, \mathrm{~g}_{2}=$ is the face area of major $\log$ diameter $\mathrm{m}^{2}, \mathrm{~g}_{1,2}=\frac{\pi \mathrm{Dhw}^{2}}{1000}$, Dhw is derived from equation 9 and equation 13, and length varies according to the following conditions:

1. For heartwood total volume $\left(\mathrm{m}^{3}\right)$, the length is Hhw (maximum heartwood height $(\mathrm{m})$ obtained from equation 6$), g_{1}$ is derived from equations 9 and 13 and $g_{2}$ is 0 .

2. For heartwood volume merchantable $\left(\mathrm{m}^{3}\right)$, the minimal heartwood diameter was established at $7 \mathrm{~cm}$ according to the international market (Ugalde 2013), $\mathrm{g}_{1}$ is derived from equations 9 and 13 and $\mathrm{g}_{2}$ is calculated with a diameter of $7 \mathrm{~cm}$.

3. For tradable sawlog production, international market establishes logs of $2.3 \mathrm{~m}$ with $7 \mathrm{~cm}$ in minimal heartwood diameter (Ugalde 2013); $\mathrm{g}_{1,2}=\frac{\pi \mathrm{Dhw}}{1000}$, and Dhw is derived from equations 9 and 13 . 


\section{Statistical analyses}

The models were fitted using ordinary least squares regression analysis and a sample of only $90 \%$ of the original data. The best model was selected using the following criteria: (1) coefficient of determination $\left(\mathrm{r}^{2}\right)$, which was defined as the square correlation coefficient between the measured and estimated values (Nagelkerke 1991); (2) the root mean square error (RMSE) (Chai \& Draxler 2014); (3) the coefficient of variation (CV); (4) the Akaike information criterion (AIC) (Akaike 1974), (5) presence of autocorrelation of variables and Durbin-Watson $(\mathrm{dW})$ test (Nerlove \& Wallis 1966); and (6) residual distribution and Shapiro-Wilk (W) test for normality distribution (Draper \& Smith 1998). Proc REG was used in all models (equations 1-4) and all criteria in the determination of the best model.

Also the selected models were validated using $10 \%$ of the original data which was not used in the model determination, and criteria used in the validation were the Wilcoxon test for paired observations (Sheskin 1997), and the skewness coefficients of the residuals.

\section{Equation systems application}

The equation systems were used to present the profile of the prediction of the heartwood diameter and the percentage of heartwood at different sampling heights for $T$. grandis trees of different dbh. In addition, the equation systems were used to present total heartwood volume and number of tradable sawlog for $T$. grandis trees of different heights and dbh. These best fit equations (models for Hhw prediction, estimation of Dhw for any given dub, and taper equation to estimate external tree diameter) were also used to determine the amount of tradable sawlog for trees of different dbh.

\section{RESULTS}

\section{Prediction of the maximum height of heartwood}

The maximum Hhw was positively related with plantation age, $\mathrm{H}$ and dbh (Figure 2). Maximum height to which heartwood grew increased with tree age up to a maximum $22 \mathrm{~m}$ when tree age was close to 15 years (Figure 2a). There was a linear relationship between $h$ and Hhw (Figure
$2 b)$. The relationship between Hhw and dbh and Hhw and age is similar since tree age and dbh are closely related (Figures $2 \mathrm{a}$ and $\mathrm{c}$ ).

The equations developed to estimate tree Hhw are shown in Table 2. All the tested equations had satisfactory behaviour of the residuals and any autocorrelation was not found (Table 2). Shapiro-Wilk test for residues showed normality $(\mathrm{p}<0.01)$, i.e. they were uniformly distributed along a zero horizontal line with no significant trend as the estimated Hhw increased. Regression coefficients $b_{3}, b_{4}, b_{5}$, and $b_{6}$ of equation 1 were not statistically different to zero, and therefore, Hhw estimation did not depend on the region from where the trees were collected. The collected data were obtained from regions of different climatic conditions, but the data were not related to the variation observed in Hhw. The observed variation in Hhw was highly dependent on total tree height and age, and to a lesser extent on tree dbh (Figure 2).

Equation 6 was a better model. It included tree age as an independent variable, which could be difficult to ascertain in unmanaged teak plantations. If tree age was unknown, the model for prediction of Hhw using $\mathrm{H}$ and dbh values could be used but in such scenario (equation 7), it was recommended to estimate tree heartwood height. The residual plot of equation 6 presented a satisfactory behaviour (Figure 3a), and Shapiro-Wilk test for residual normality was significant (Table 2 ). In addition, the parameters that were determined, CV, AIC, RMSE and Durbin-Watson test were the lowest between different equations. Besides, its validation using the selected independent sample of data, and a Wilcoxon-paired test, indicated that the model was not skewed $(p=0.33)$. The estimated coefficient of skewness was $-4.2 \%$.

\section{Prediction of external tree diameter at any height}

Figure 4 shows that $\mathrm{d} / \mathrm{dbh}$ and $\mathrm{h} / \mathrm{H}$ are inversely correlated, and the collected tree samples have similar taper. This graph also shows the wide variation of the diameter of the tree base, that is, when $\mathrm{h} / \mathrm{H}$ is zero, where teak tree bole is no longer cylindrical but star shaped. The equations proposed to describe tree diameter under bark profiles are shown in Table 3. Equation 9 yielded the best results, with the highest $r^{2}$ values, and the lowest values in CV, AIC, RMSE and any 

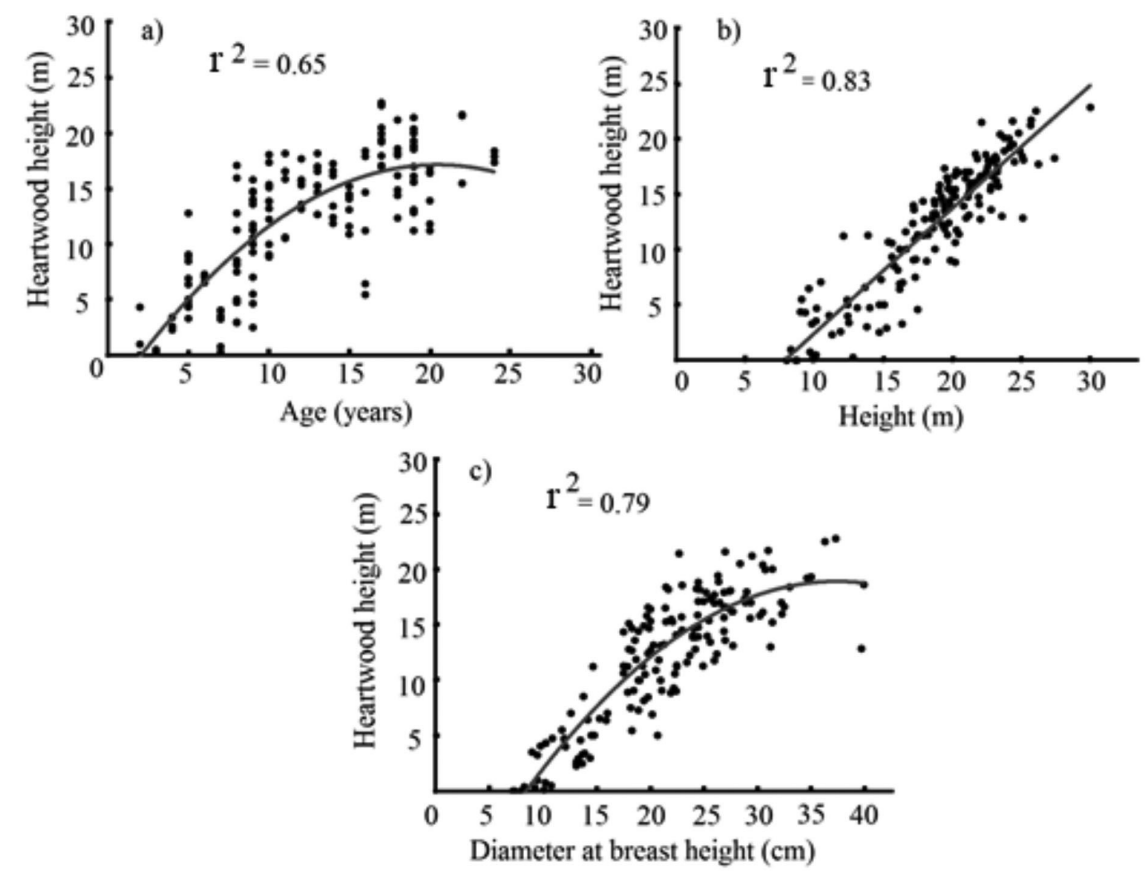

Figure 2 Relationship of maximum heartwood height with (a) age, (b) total height and (c) diameter at breast height for T. grandis

Table 2 Regression models and statistics for the maximum height of heartwood of T. grandis trees from plantations in Costa Rica

\begin{tabular}{ccccccc}
\hline $\begin{array}{c}\text { Model detailed } \\
\text { in equation: }\end{array}$ & $\mathrm{r}^{2}$ & CV & AIC & RMSE & dW & W \\
\hline$(1)$ & 0.74 & 25.03 & 322.96 & 3.04 & 1.45 & 0.1072 \\
$(2)$ & 0.71 & 25.99 & 390.9 & 3.16 & 1.43 & 0.0909 \\
$(3)$ & 0.82 & 20.48 & 262.67 & 2.49 & 1.51 & 0.3256 \\
$(4)$ & 0.87 & 17.46 & 218.03 & 2.12 & 1.56 & 0.0057 \\
$(5)$ & 0.79 & 22.55 & 291.18 & 2.74 & 1.36 & 0.0565 \\
$(6)$ SM & 0.88 & 17.07 & 212.57 & 2.07 & 1.58 & 0.0014 \\
$(7)$ & 0.84 & 19.38 & 247.82 & 2.35 & 1.55 & 0.1053 \\
\hline
\end{tabular}

$\mathrm{r}^{2}=$ coefficient of determination, $\mathrm{CV}=$ coefficient of variation, $\mathrm{AIC}=$ Akaike information criterion, RMSE = root mean square error, $\mathrm{dW}=$ Durbin-Watson test, $\mathrm{W}=$ Shapiro-Wilk test for residual normality, ${ }^{\mathrm{SM}}=$ selected model
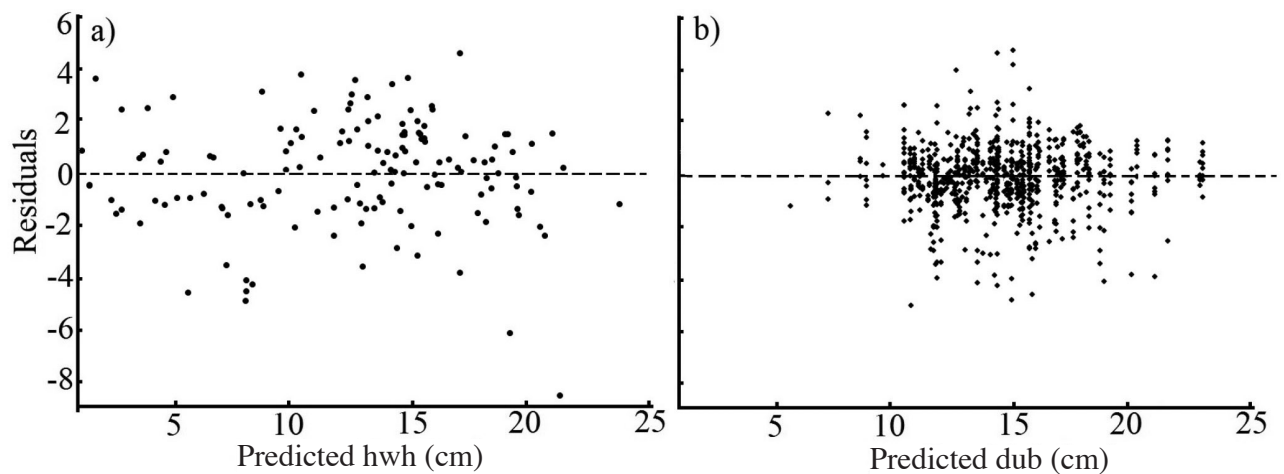

Figure 3 Distribution of the residuals with respect to predicted value for (a) equation 6 and (b) equation 9 (as in Tables 3 and 4 respectively) 


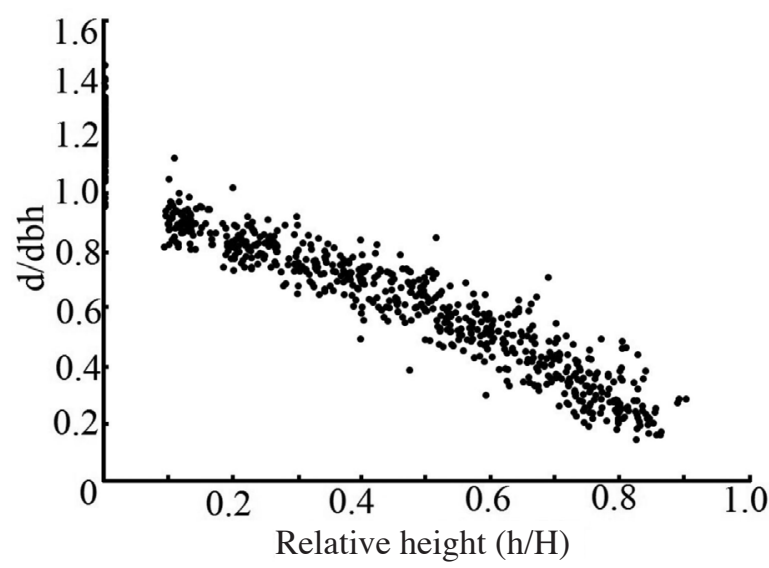

Figure 4 Relation between ratio of total diameter of tree (d)/diameter at breast height $(\mathrm{dbh})$ and ratio of sampling height $(\mathrm{h}) /$ total height $(\mathrm{H})$ for $T$. grandis

Table 3 Regression models and statistics for the proposed taper equation to estimate external tree diameter with bark at a specific tree height $(\mathrm{h})$ for $T$. grandis trees

\begin{tabular}{lcccccc}
\hline $\begin{array}{c}\text { Model } \\
\text { detailed in } \\
\text { equation: }\end{array}$ & $\mathrm{r}^{2}$ & CV & AIC & RMSE & $\mathrm{dW}$ & SW \\
\hline$(8)$ & 0.96 & 14.34 & 488.16 & 0.96 & 0.82 & 0.0001 \\
$(9)^{\mathrm{SM}}$ & 0.91 & 5.69 & -2853.46 & 0.15 & 1.10 & 0.0001 \\
$(10)$ & 0.88 & 16.48 & 1313.67 & 2.41 & 1.27 & 0.0001 \\
$(11)$ & 0.87 & 16.84 & 1346.47 & 2.46 & 1.25 & 0.0001 \\
$(12)$ & 0.67 & 10.66 & -17345.71 & 0.26 & 1.09 & 0.0001 \\
$(13)$ & 0.88 & 6.55 & -1617.43 & 0.33 & 1.15 & 0.0001 \\
\hline
\end{tabular}

$\mathrm{r}^{2}=$ coefficient of determination, $\mathrm{CV}=$ coefficient of variation, AIC = Akaike information criterion, RMSE = root mean square error, $\mathrm{dW}=$ Durbin-Watson test, $\mathrm{SW}=$ Shapiro-Wilk test for residual normality, ${ }^{\mathrm{SM}}=$ selected model

autocorrelation, according to Durbin-Watson test. All the regression coefficients of the model were significantly different (Table 4), and it was also the model that demonstrated better behaviour of the residuals (Figure $3 \mathrm{~b}$ ), showing no correlation between them to predicted values $(\mathrm{p}=0.05)$, but great variation when $h$ was zero, that was the tree base. Validation of equation 9 for taper indicated a skewness coefficient equal to $0.39 \%(p=0.29)$, indicating that predicted diameter under bark and observed diameter under bark values were not statistically significant.

\section{Prediction of heartwood diameter at any given height}

Heartwood diameter (Dhw) at any tree height was positively and linearly correlated with external tree diameter at the same height (d). Figure 5 shows that it was possible to predict
Dhw using a simple linear regression model shown in equation 8 , and the parameters of this equations were appropriated (Table 3 ). The validation of the model prepared indicated that it was not skewed $(p=0.26)$; it had a skewness coefficient equal to $-1.73 \%$. The equations developed to estimate Dhw and its corresponding characteristics of use are presented in Table 5. It is important to note that the use of this model was restricted to external stem diameters greater than $6.1 \mathrm{~cm}$, otherwise the value must be set to zero.

Equation systems application: estimation of heartwood profile, heartwood volume and tradable sawlog

The system of equations to estimate heartwood profile is presented in Table 5. Equation 6 established the limit up to which equation 9 could be used, setting the maximum height of 
Table 4 Parameters for simultaneous fitting of the equation system for T. grandis trees

\begin{tabular}{cccc}
\hline Model detailed in equation: & Parameter & Estimate & Standard error \\
\hline \multirow{3}{*}{$(6)$} & $\mathrm{b}_{1}$ & -7.768 & 0.70 \\
& $\mathrm{~b}_{2}$ & 0.725 & 0.07 \\
& $\mathrm{~b}_{3}$ & 0.293 & 0.04 \\
& $\mathrm{~b}_{4}$ & 0.134 & 0.05 \\
\hline \multirow{3}{*}{$(8)$} & $\mathrm{b}_{0}$ & -4.83 & 0.19 \\
& $\mathrm{~b}_{1}$ & 0.99 & 0.00 \\
\hline & $\mathrm{a}_{0}$ & -0.242 & 0.18 \\
& $\mathrm{a}_{1}$ & 1.025 & 0.05 \\
& $\mathrm{a}_{2}$ & 0.018 & 0.08 \\
& $\mathrm{~b}_{1}$ & 0.441 & 0.05 \\
& $\mathrm{~b}_{2}$ & 0.027 & 0.18 \\
& $\mathrm{~b}_{3}$ & 0.877 & 0.05 \\
& $\mathrm{~b}_{4}$ & -6.076 & 1.25 \\
& $\mathrm{~b}_{5}$ & -0.003 & 0.01 \\
& $\mathrm{~b}_{6}$ & -0.147 & 0.10 \\
\hline
\end{tabular}

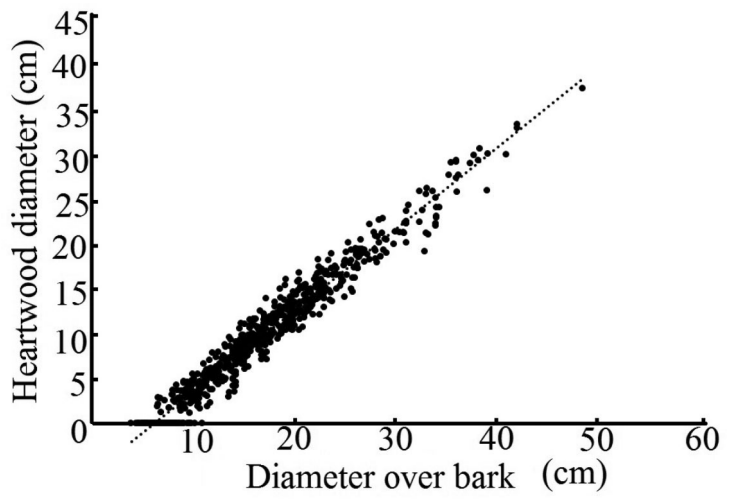

Figure 5 Relation of the heartwood diameter with external trunk diameter at any given height for T. grandis

the hardwood (Hhw). For example, a teak tree of $20 \mathrm{~m}$ height, and a dhb with bark of $28 \mathrm{~cm}$, had a heartwood height of approximately $15 \mathrm{~m}$. Using this value of height in equation 8 yielded an external tree diameter of $10 \mathrm{~cm}$ and a Dhw approximately $3.8( \pm 3.0) \mathrm{cm}$.

Using the equations of the system presented in Table 5, it was also possible to prepare the curves predicting Dhw at varying heights and $\mathrm{dbh}$ for the teak trees, and also the heartwood percentage at different tree heights (Figure 5). Total commercial heartwood volume for trees of different $h$ and $d b h$ was predicted based on the equations in Table 6. They also allowed estimation of tradable sawlogs of a given minimal heartwood diameter (i.e. $7 \mathrm{~cm}$ and it was used in the systems of equations of Table 5), and correspondingly allowed determination of the commercial log length (2.3 $\mathrm{m}$ in Table 6$)$. As expected, the smaller the diameter, the lesser is the amount of tradable sawlogs; whereas the higher the dbh and height values, the greater is the amount of tradable sawlogs (Figure 6). Notably, a log that can be traded in the international market (2.3 $\mathrm{m}$ length and more than $7 \mathrm{~cm}$ of heartwood diameter) was obtained when the tree had a dbh value of at least $16 \mathrm{~cm}$ (Figure 6) and, an additional tradable sawlog was obtained if the tree increased approximately $4 \mathrm{~cm}$ in $\mathrm{dbh}$.

\section{DISCUSSION}

Tree heartwood profile of teak trees presented a conical shape (Climent et al. 2003), as was in the sample trees used in this study (Figure 2). Hhw is influenced by conditions in the plantation such as management, dbh, tree height and crown development (Yang et al. 1994). Various studies presented models to estimate tree total height (H) of teak trees, such as the model devised by Akindele (1991) for 20-year-old plantation trees in Nigeria, or those developed by Upadhyay et al.(2005) for $\mathrm{H}$ and dominant height estimation for 4--10-year-old Indian teak trees. However, no models exist specifically for determination of Hhw in teak trees based on $\mathrm{H}$, tree age or $\mathrm{dbh}$, as the one developed in this study (Table 2; equations 6 and 7$)$. 
Table 5 System of equations to estimate heartwood diameters and volume of $T$. grandis trees

\begin{tabular}{|c|c|c|c|}
\hline Model & $r^{2}$ & Range of values of sample & No. observation \\
\hline $\begin{array}{l}\text { Equation 6: Estimation of tree heartwood height }(\mathrm{m}) \\
\text { Hhw }=-7.768+0.725 \times \mathrm{H}+0.293 \text { Age }+0.13 \mathrm{dbh}\end{array}$ & 0.87 & $\begin{array}{l}\text { Hhw: } 0-22.8 \mathrm{~m} \\
\text { H: } 8-30 \mathrm{~m} \\
\text { Age: } 2-24 \text { years } \\
\text { dbh: } 7.2-39.9 \mathrm{~cm}\end{array}$ & 143 \\
\hline $\begin{array}{l}\text { Equation 8: Estimation of heartwood diameter (Dhw) } \\
\text { for any given tree external diameter (dub), If di }>6.1 \mathrm{~cm}\end{array}$ & 0.96 & $\begin{array}{l}\text { Dhw: } 3.8-48.8 \mathrm{~cm} \\
\text { d: } 0-37.3 \mathrm{~cm}\end{array}$ & 670 \\
\hline \multicolumn{4}{|l|}{$\mathrm{Dhw}=-4.83+0.99 \times \mathrm{dub}$} \\
\hline \multicolumn{4}{|l|}{ Otherwise $\mathrm{Dh} \mathrm{w}=0$} \\
\hline $\begin{array}{l}\text { Equation 9: Estimation of tree external diameter under } \\
\text { bark (dud) at a specific tree height }(\mathrm{h}) \\
\mathrm{dub}=\mathrm{a}_{0} \mathrm{dbh}^{\mathrm{a} 1} \mathrm{H}^{\mathrm{a} 2} \mathrm{X}^{\mathrm{M}}\end{array}$ & 0.94 & $\begin{array}{c}\text { dub: } 3.8-48.8 \mathrm{~cm} \\
\text { dbh: } 9.0-39.9 \mathrm{~cm} \\
\text { H: } 9.0-30 \mathrm{~m} \\
\text { h: } 0-24 \mathrm{~m} \\
\text { dub: } 0-37.3 \mathrm{~cm}\end{array}$ & 670 \\
\hline
\end{tabular}

Equation 14: Estimation of the heartwood volume

$\mathrm{hwv}=\frac{\left(\mathrm{g}_{1}+\mathrm{g}_{2}\right)}{2} \times$ Length
Equation 14 was used for determination of: heartwood total volume $\left(\mathrm{m}^{3}\right)$, heartwood volume merchantable $\left(\mathrm{m}^{3}\right)$ and tradable sawlog

Table 6 Total heartwood volume $\left(\mathrm{m}^{3}\right)$ and number of tradable logs for teak trees of different heights and diameters at breast height

\begin{tabular}{|c|c|c|c|c|c|c|c|c|c|c|}
\hline \multirow{2}{*}{$\begin{array}{c}\text { Height } \\
(\mathrm{m})\end{array}$} & \multicolumn{10}{|c|}{ Diameter at breast height $(\mathrm{cm})$} \\
\hline & 12 & 14 & 16 & 18 & 20 & 22 & 24 & 26 & 28 & 30 \\
\hline 15 & & & $0.024(1)$ & $0.051(1)$ & $0.058(1)$ & $0.068(2)$ & $0.088(2)$ & $0.111(3)$ & $0.136(3)$ & $0.165(4)$ \\
\hline 17 & & & $0.027(1)$ & $0.039(1)$ & $0.055(1)$ & $0.074(2)$ & $0.095(2)$ & $0.120(3)$ & $0.147(3)$ & $0.177(4)$ \\
\hline 19 & & & & $0.043(1)$ & $0.060(1)$ & $0.080(2)$ & $0.103(2)$ & $0.129(3)$ & $0.158(3)$ & $0.190(4)$ \\
\hline 21 & & & & & $0.062(1)$ & $0.083(2)$ & $0.108(2)$ & $0.135(3)$ & $0.166(3)$ & $0.200(4)$ \\
\hline 23 & & & & & & $0.092(2)$ & $0.117(2)$ & $0.147(3)$ & $0.179(3)$ & $0.216(4)$ \\
\hline 25 & & & & & & & $0.121(2)$ & $0.152(3)$ & $0.187(3)$ & $0.224(4)$ \\
\hline
\end{tabular}

Numbers in parentheses are the estimated numbers of tradable logs; values were derived using the system of equations presented in Table 3 with minimal tradable heartwood diameter $7 \mathrm{~cm}$ and length of tradable $\log 2.3 \mathrm{~m}$

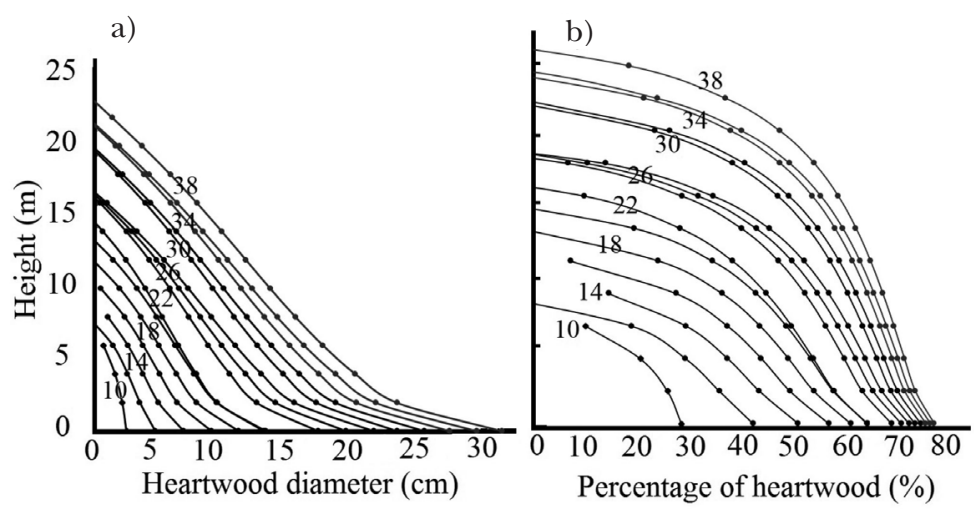

Figure 6 Prediction of (a) heartwood diameter, and (b) percentage of heartwood at different sampling heights for $T$. grandis trees of different dbh; numbers alongside $=$ different $\mathrm{dbh}$ 
Many studies of other tropical species have correlated Hhw based on $\mathrm{H}$, tree age or dbh (Cardoso \& Pereira 2017). Nonetheless, little research has been carried out to develop models to predict Hhw based on such variables. Thus, our study shows the significance of the three factors in heartwood formation. For this reason, equation 6 was selected for $T$. grandis (Table 2).

Notably, although determination of Dhw with tree age has been thoroughly studied (Pérez \& Kanninen 2003, 2005), few studies have related these parameters with varying heights in teak trees (Garcia et al. 2011). In Costa Rica, the studies by García et al. (2011) for teak heartwood from fast-growth forest plantations are the most noteworthy in regard to the heartwood prediction models. In their study, the Garay, Demaerschalk and Omerod model was developed, and the authors included $\mathrm{dbh}$ and $\mathrm{H}$ of the tree in their model. According to them, the best-fitting model for prediction of Dhw in teak trees was the Garay model, which presents similarities (low AIC, CV and RMSE values) with the Kozak, and equation 9 was selected as the best model to fit in this study for the same purpose (Table 3; equations 8 and 9). However, comparing Dhw values obtained at varying heights by the Garay model in Garcia et al. (2011), with those obtained in this study (Figure 5), it was observed that the former study was smaller in magnitude. Differences were likely due to the range of ages used in each study; for example, García et al. (2011) used trees with ages ranging from 2-8 years, whereas in this study, a broader tree age range of 2-22 years was used. The juvenile trees used in García et al. (2011) had lower Dhw values than this study and other studies like the Moya et al. (2014) in older trees.

Although Kozak's variable-exponent and Shuaibu models (equations 9 and 10) can be employed in this study, the model with the best fitting parameters was by Kozak's (1969) (Table 3 , equation 9 ), as it yielded an $r^{2}$ value closer to 1 , as well as lower sampling error. The model by Shuaibu (2016) slightly underestimated bigger diameters and slightly overestimated the smaller diameters, and this was in agreement with the data of the present study. The correlation found between the Dhw and the external tree diameter (Figure 5) agreed with other studies of teak; e.g. Pérez and Kanninen (2003) proposed a logarithmic regression model for $\mathrm{dbh}$ and Dhw for 5- -87-year-old teak in Costa Rica, also
Kokutse et al. (2010) promoted the logarithmic regression model for $\mathrm{dbh}$ and Dhw for 6 to 70 years old teak trees in Togo.

Using the system of equations presented in Table 5, it was possible to predict different tree variables. One of these was the predictive of Dhw at varying height and dbh curves (Figure 7a). Similar curves were obtained by Garcia et al. (2011) in teak trees that were 3-12 years old in Mato Grosso, Brazil. Tree taper equations are important because reliable estimates of wood products and their values are essential to quantify expected commercial harvest returns (Warner et al. 2016).

In the same way, taper equations can be used in volume tables to describe the development of woody plantations in this study. A limiting factor of these table is that they do not quantify the heartwood present in teak trees, although categorisation of most sawlogs in the international market depends on heartwood (Ugalde 2013). Therefore, for the purpose of developing estimations of heartwood volume and sawlogs, it was possible to make use of the proposed models (Table 2, model equation 6) for this as well as for estimations of sawlog distribution in volume (Figure 8).

The marketability of teakwood products in the international market depends on the amount of heartwood percentage present in the $\log$ (Ugalde 2013). The international market allows trade of logs having a minimum length and diameter as stipulated by the buyer, which is approximately $7 \mathrm{~cm}$ in diameter (Ugalde 2013). Therefore, the models developed for prediction of Dhw also allowed for prediction of tradable logs depending on diameter and height of the teak tree (Figure 8). Another notable feature of this prediction model was that an increase in dbh by $4 \mathrm{~cm}$ indicated one additional tradable sawlog at the upper part of the tree (Figure 8).

\section{CONGLUSIONS}

In spite of the variation observed in the plots as well as in the sampled trees, the results showed that heartwood diameter could be highly predicted in T. grandis at any height (h), heartwood volume (hwv), and number of logs using easy measurable tree variables such as dbh and $\mathrm{H}$.

The heartwood equations applicable to T. grandis can be used for the prediction of 


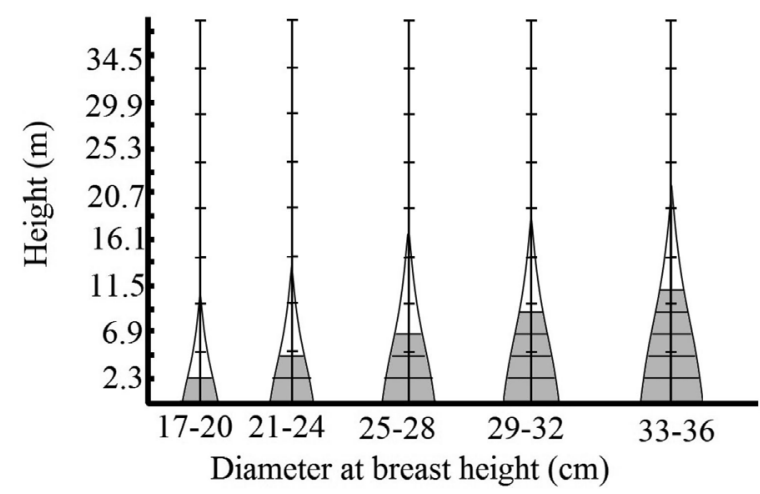

(a)

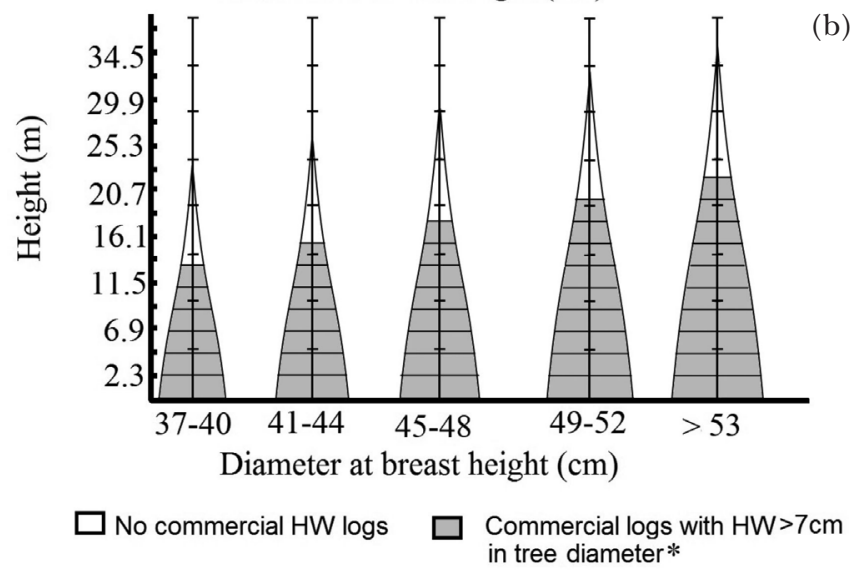

Figure 7 Representation of the commercial heartwood sawlogs in trees with different diameter at breast height and total height using the equations in Table 3; HW = heartwood; according to Ugalde (2013); the international market allows trade of logs with heartwood diameter of approximately $7 \mathrm{~cm}$

commercial heartwood log volume of any given size and Dhw from fast-growth plantations. Therefore, plantation owners can estimate their income with good precision using normal stand variables such as mean tree height, diameter, and number of trees per hectare.

\section{ACKNOWLEDGEMENTS}

The authors wish to thank the Vicerrectoría de Investigación y Extensión at the Instituto Tecnológico de Costa Rica and all companies for providing raw materials and other assistance during this study.

\section{REFERENCES}

Akaike H. 1974. A new look at the statistical model identification. IEEE Transactions on Automatic Control 19: 716-723.

Akindele SO. 1991. Development of a site index equation for teak plantations in southwestern Nigeria. Forest Science 4: 162-169. Development of a site index equation.
Anish MC, Anoop EV, Vishnu R, Sreejith B \& Jijeesh CM. 2015. Effect of growth rate on wood quality of teak (Tectona grandis L. f.): a comparative study of teak grown under differing site quality conditions. Journal of the Indian Academy of Wood Science 12: 81-88.

Berrocal A, Gaitan-Alvarez J, Moya R, Fernández-Sólis D \& Ortiz-Malavassi E. 2018. Development of heartwood, sapwood, bark, pith and specific gravity of teak (Tectona grandis) in fast-growing plantations in Costa Rica. Journal of Forestry Research 31: 667-676.

Cardoso S \& Pereira H. 2017. Characterization of Douglasfir grown in Portugal: heartwood, sapwood, bark, ring width and taper. European Journal of Forest Research 136: 597-607.

Chai T \& Draxler RR. 2014. Root mean square error (RMSE) or mean absolute error (MAE). Geoscientific Model Development Discussions 7: 1525-1534.

Climent J, Chambel MR, Gil L \& Pardos JA. 2003. Vertical heartwood variation patterns and prediction of heartwood volume in Pinus canariensis Sm. Forest Ecology and Management 174: 203-211.

Draper NR \& Smith H. 1998. Applied Regression Analysis. Volume 326 Series in Probability and Statistics. John Wiley and Sons, New York.

Fernández-Sólis D, Berrocal A \& Moya R. 2018. Heartwood formation and prediction of heartwood parameters 
in Tectona grandis L.f. trees growing in forest plantations in Costa Rica. Bois et Forets des Tropiques 335: 25-37.

Fonweban J, Gardiner B \& Auty D. 2012. Variable-top merchantable volume equations for Scots pine (Pinus sylvestris) and Sitka spruce (Picea sitchensis (Bong.) Carr.) in northern Britain. Forestry 85: 237-253.

Garcia HL, Da Silva MLM, Binoti DHB, Fardin L \& TakizaWa FH. 2011. Estimation of inside-bark diameter and heartwood diameter for Tectona grandis Linn. trees using artificial neural networks. European Journal of Forest Research 130: 263-269.

Hegde HT, Kalkoor MA, Jha SK \& Thakur NS. 2014. Evaluation of variation in physical properties of wood among some tropical tree species of south India. Indian Forester 140: 70-75.

Heidarsson L \& Pukkala T. 2011. Taper functions for lodgepole pine (Pinus contorta) and siberian larch (Larix sibirica) in Iceland. Icelandic Agricultural Sciences 24: 3-11.

Kokutse AD, Stokes A, Kokutse NK \& Kokou K. 2010. Which factors most influence heartwood distribution and radial growth in plantation teak? Annals of Forest Science 67: 407-407.

KozaK A. 2004. My last words on taper equations. The Forestry Chronicle 80: 507-515.

Kozak A, Munro DD \& SMith JHG. 1969. Taper functions and their application in forest inventory. The Forestry Chronicle 45: 278-283.

Leite HG, Da Silva MLM, Binoti DHB, Fardin L \& Takizawa FH. 2011. Estimation of inside-bark diameter and heartwood diameter for Tectona grandis Linn. trees using artificial neural networks. European Journal of Forest Research 130: 263-269.

Moya R, Bond B \& Quesada H. 2014. A review of heartwood properties of Tectona grandis trees from fast-growth plantations. Wood Science and Technology 48: 411-433.

NAGELKERKE NJD. 1991. A note on a general definition of the coefficient of determination. Biometrika 78: 691-692.

Nerlove M \& Wallis KF. 1966. Use of the Durbin-Watson Statistic in inappropriate situations. Econometrica 34: 235-238.

Nunifu TK \& Murchison HG. 1999. Provisional yield models of teak (Tectona grandis Linn F.) plantations in northern Ghana. Forest Ecology and Management 120: 171-178.

Pérez LD \& Kanninen M. 2003. Heartwood, sapwood and bark content, and wood dry density of young and mature teak (Tectona grandis) trees grown in Costa Rica. Silva Fennica 37: 45-54.

Pérez D \& Kanninen M. 2005. Stand growth scenarios for Tectona grandis plantations in Costa Rica. Forest Ecology and Management 210: 425-441

SHESkIN DJ. 1997. Handbook of Parametric and Nonparametric Statistical Procedures. The American Statistician. Chapman \& Hall/CRC, Boca Raton.

Shuaibu R. 2016. Developing stem taper equation for Tectona grandis (teak) plantation in Agudu forest reserve, Nasarawa state, Nigeria. Journal of Science E Technology 5: 199-206.

Tewari V, Álvarez-González J \& García O. 2014. Developing a dynamic growth model for teak plantations in India. Forest Ecosystems 1: 9-16.

Thulasidas PK, Bhat KM \& Okuyama T. 2006. Heartwood colour variation in home garden teak (Tectona grandis) from wet and dry localities of Kerala, India. Journal of Development of a Site Index Equation Science 18: 51-54.

Ugalde L. 2013. Teak: New Trends in Silviculture: Commercialization and Wood Production. International Forestry and Agroforestry, Cartago.

Upadhyay A, Eid T \& Sankhayan PL. 2005. Construction of site index equations for even aged stands of Tectona grandis (teak) from permanent plot data in India. Forest Ecology and Management 212: 14-22.

Wang X, Wang C, Zhang Q \& Quan X. 2010. Heartwood and sapwood allometry of seven Chinese temperate tree species. Annals of Forest Science 67: 410-410.

Warner AJ, Jamroenprucksa M \& Puangchit L. 2016. Development and evaluation of teak (Tectona grandis L.f.) taper equations in northern Thailand. Agriculture and Natural Resources 50: 362-367.

Yang KC, Chen YS, Chiu C \& Hazenberg G. 1994. Formation and vertical distribution of sapwood and heartwood in Cryptomeria japonica D. Don. Trees 9: 35-40.

Yang B, Jia H, Zhao Z, Pang S \& Cai D. 2020. Horizontal and vertical distributions of heartwood for teak plantation. Forests 11: 200-225. 